\title{
Campylobacter insulaenigrae sp. nov., isolated from marine mammals
}

Correspondence Geoffrey Foster g.foster@ed.sac.ac.uk

\author{
Geoffrey Foster, ${ }^{1}$ Barry Holmes, ${ }^{2}$ Arnold G. Steigerwalt, ${ }^{3}$ Paul A. Lawson, ${ }^{4}$ \\ Petra Thorne, ${ }^{5}$ Dorothy E. Byrer, ${ }^{3}$ Harry M. Ross, ${ }^{1}$ Jacqueline Xerry, ${ }^{6}$ \\ Paul M. Thompson ${ }^{7}$ and Matthew D. Collins ${ }^{4}$ \\ 1SAC Veterinary Services, Drummondhill, Stratherrick Road, Inverness IV2 4JZ, UK \\ ${ }^{2}$ Health Protection Agency, National Collection of Type Cultures, Central Public Health \\ Laboratory, London NW9 5HT, UK \\ ${ }^{3}$ Centers for Disease Control and Prevention, US Department of Health and Human Services, \\ 1600 Clifton Road NE, Atlanta, GA 30333, USA \\ ${ }^{4}$ School of Food Biosciences, University of Reading, Whiteknights, Reading RG6 6AP, UK \\ ${ }^{5}$ School of Natural and Environmental Sciences, Coventry University, Priory Street, Coventry \\ CV1 5FB, UK \\ ${ }^{6}$ Health Protection Agency, Helicobacter Reference Unit, Central Public Health Laboratory, \\ London NW9 5HT, UK \\ ${ }^{7}$ University of Aberdeen, School of Biological Sciences, Lighthouse Field Station, Cromarty, \\ Ross-shire IV11 8YJ, UK
}

\begin{abstract}
Phenotypic and phylogenetic studies were performed on four Campylobacter-like organisms recovered from three seals and a porpoise. Comparative 16S rRNA gene sequencing studies demonstrated that the organisms represent a hitherto unknown subline within the genus Campylobacter, associated with a subcluster containing Campylobacter jejuni, Campylobacter coli and Campylobacter lari. DNA-DNA hybridization studies confirmed that the bacteria belonged to a single species, for which the name Campylobacter insulaenigrae sp. nov. is proposed. The type strain of Campylobacter insulaenigrae sp. nov. is NCTC $12927^{\top}$ (=CCUG $48653^{\top}$ ).
\end{abstract}

In 1913, McFadyean \& Stockman recorded the isolation of Vibrio fetus in pure culture and its association with abortion in sheep and cattle (McFadyean \& Stockman, 1913). In 1963, this organism was transferred to the newly proposed genus Campylobacter (Sebald \& Véron, 1963). During the 1970s, a renewed interest in Campylobacter followed the recognition of Campylobacter jejuni and Campylobacter coli as a cause of diarrhoea in humans (Cooper \& Slee, 1971; Dekeyser et al., 1972) and campylobacters soon became recognized as the commonest bacterial cause of enteritis (Griffiths \& Park, 1990; Penner, 1988). In addition, the implementation of improved phylogenetic methods of analysis permitted closer taxonomic scrutiny of these organisms, resulting in several novel species, and led to the proposal of rRNA superfamily VI of the Proteobacteria as including the genera

Published online ahead of print on 24 September 2004 as DOI 10.1099/ijs.0.63147-0.

Abbreviation: SAFLP, single-enzyme amplified-fragment length polymorphism.

The GenBank/EMBL/DDBJ accession number for the 16S rRNA gene sequence of NCTC $12927^{\top}$ is AJ620504.
Campylobacter, Helicobacter and Arcobacter (Vandamme et al., 1991). According to On (2001), the genus Campylobacter contains 16 species with a further six subspecies. In the course of bacteriological investigations of rectal swabs from free-ranging seals and also following post-mortem examination of seals and cetaceans, four Campylobacter-like organisms were recovered from three seals and a porpoise. In this paper, we describe the cultural and biochemical characteristics of these bacteria and the results of a polyphasic taxonomic investigation.

Three Campylobacter-like organisms were isolated from rectal swabs collected from three common seals (Phoca vitulina) during a capture-release programme (Thompson et al., 1992). A fourth strain was recovered from a sample of small intestine taken from a harbour porpoise (Phocoena phocoena) carcass submitted under the Scottish Strandings Scheme. Isolation was made on Columbia blood agar base (Oxoid) supplemented with Blaser-Wang selective supplement (Oxoid) and 5\%(w/v) citrated sheep blood agar (CSBA) (Oxoid). Plates were incubated at $37^{\circ} \mathrm{C}$ in a microaerobic atmosphere achieved by jar evacuation and filling with a prepared gas mixture containing $\mathrm{N}_{2} / \mathrm{CO}_{2} / \mathrm{O}_{2}$ 
$(84: 10: 6)$. Culture plates were examined for growth after 2, 4 and 7 days incubation. Isolates were transferred to fresh citrated sheep blood agar plates for maintenance and characterization tests. The four strains were examined in a range of tests, the methods for most of which have been described by On \& Holmes (1995), taking special note, where appropriate, of inoculum size as recommended in On \& Holmes (1991). Acid production from carbohydrates was tested for in peptone yeast sugars. For motility determination, a blood-agar slope was inoculated with a broth suspension of the organism until a small amount of the inoculum remained at the base of the slope. Following overnight incubation, motility was determined from microscopic examination of a wet preparation of the broth at the base of the slope. Nitrate reduction was tested by adding Greiss-Ilosvay's reagents nos 1 and 2 (Merck) to a $24 \mathrm{~h}$ culture in nutrient broth no. 2 (Unipath) containing $1 \%$ $(\mathrm{w} / \mathrm{v}) \mathrm{KNO}_{2}$. Antibiotic-susceptibility tests were carried out by disc diffusion using cephalothin $(30 \mu \mathrm{g})$ and nalidixic acid $(30 \mu \mathrm{g})$ discs (Oxoid).

$16 \mathrm{~S}$ rRNA genes of the isolates were amplified by a PCR using universal primers pA (sequence 5'-AGAGTTTGATCCTGGCTCAG- $3^{\prime}$, corresponding to positions $8-28$ in Escherichia coli numbering) and $\mathrm{pH}$ (sequence 5'-AAGGAGGTGATCCAGCCGCA-3', positions 1542-1522 in E. coli numbering) and directly sequenced using a Taq DyeDeoxy terminator cycle sequencing kit (Applied Biosystems) and an automatic DNA sequencer (model 373A; Applied Biosystems). The closest known relatives of the novel isolates were determined by searching the GenBank database using FASTA (Lipman \& Pearson, 1985). These sequences and those of other known related strains were retrieved from GenBank and aligned with the newly determined sequences using the program DNATools (Rasmussen, 1995). The resulting multiple sequence alignment was corrected manually and a distance matrix was calculated with the programs PRETTY and DNADIST (using the Kimura-2 correction parameter) (Felsenstein, 1989). A phylogenetic tree was constructed according to the neighbour-joining method with the program NEIGHBOR, and the stability of the groupings was estimated by bootstrap analysis (500 replications) using the programs DNABOOT, DNADIST, NEIGHBOR and CONSENSE (Felsenstein, 1989). For DNA-DNA hybridization, the bacterial cells were lysed and DNA was isolated and purified according to the method of Brenner et al. (1982). DNA from strain NCTC $12927^{\mathrm{T}}$ was labelled with $\left[{ }^{32} \mathrm{P}\right] \mathrm{dCTP}$ by utilizing a nick translation kit (Invitrogen Life Technologies). This preparation was tested for reassociation to unlabelled DNA from the same strain and to the three other Campylobacter isolates as well as to DNAs from the type strains of Campylobacter lari, C. jejuni and C. coli. Relative binding ratios and divergence were calculated as described by Brenner et al. (1982). All reactions were done in duplicate at both the optimal temperature $\left(50^{\circ} \mathrm{C}\right)$ and the stringent temperature $\left(65^{\circ} \mathrm{C}\right)$. The clonality of the four Campylobacter-like organisms was investigated by amplified fragment length polymorphism
(AFLP) fingerprinting for which DNA was extracted as previously described by Gibson et al. (1998). A single-enzyme AFLP (SAFLP) method was used in which the DNA was diluted to a concentration of $0 \cdot 266 \mu \mathrm{g} \mu \mathrm{l}^{-1}$. The SAFLP method was carried out as described by Champion et al. (2002) except that PCR amplification was performed in a Sprint thermal cycler (Hybaid). Cluster analysis was performed with BIONUMERICS (Applied Maths), using the Dice correlation coefficient and the UPGMA clustering algorithm.

Four strains of Gram-negative, comma-shaped bacilli morphologically similar to Campylobacter were isolated from rectal swabs taken from three common seals and the intestinal contents of a porpoise. The organisms were catalase-positive, oxidase-positive and motile. Colonies of all the isolates, when grown on CSBA at $37^{\circ} \mathrm{C}$ in a microaerobic atmosphere, were $0.75-1.0 \mathrm{~mm}$ in diameter, circular, entire, low-convex, smooth, shiny, grey, translucent, butyrous and easily emulsified. Swarming did not occur. Growth did not occur at either 25 or $42^{\circ} \mathrm{C}$, nor did it occur in aerobic or anaerobic conditions. Growth did occur on unsupplemented nutrient agar and in the presence of $1 \%$ $(\mathrm{w} / \mathrm{v})$ glycine but not in the presence of 2 or $3.5 \%(\mathrm{w} / \mathrm{v})$ $\mathrm{NaCl}$. Urease was not produced. Nitrates were reduced but nitrites were not reduced. The strains were nonsaccharolytic and were resistant to $30 \mu \mathrm{g}$ cephalothin $\mathrm{ml}^{-1}$ and $30 \mu \mathrm{g}$ nalidixic acid $\mathrm{ml}^{-1}$. Hydrogen sulphide was produced in triple-sugar-iron (TSI) agar. Hippurate and indoxyl acetate were not hydrolysed.

To clarify the taxonomic interrelationships of the unidentified isolates, their 16S rRNA gene sequences were determined. The almost complete gene sequences of all four strains were elucidated and pairwise comparisons showed that all of the isolates were genetically highly related to each other, exhibiting $99 \cdot 9-100 \%$ sequence similarity (based on a comparison of approximately 1400 bases). The 16S rRNA gene sequence ( $>1400 \mathrm{nt}$ ) of a representative strain (NCTC $12927^{\mathrm{T}}$ ) was subjected to searches of GenBank/EMBL, which confirmed that the unknown bacterium was phylogenetically most closely related to the genus Campylobacter (data not shown). A tree constructed using the neighbourjoining method and depicting the phylogenetic position of the unidentified organism within the genus Campylobacter is shown in Fig. 1. The unknown bacterium formed a distinct subline within the genus, associated with a subcluster of species that included C. jejuni subsp. jejuni and subsp. doylei, C. lari and C. coli. Pairwise sequence comparisons revealed similarities of $98 \cdot 8,98 \cdot 3$ and $97 \cdot 6 \%$, respectively, with the aforementioned species. Other Campylobacter species displayed substantially lower levels of similarity (data not shown).

In view of the high $16 \mathrm{~S}$ rRNA gene sequence similarity between the unidentified isolates and C. jejuni, C. lari and C. coli, chromosomal DNA-DNA pairing was conducted. The results of these DNA-DNA hybridization studies are shown in Table 1. The four sea-mammal isolates displayed relative binding ratios $>70 \%$ under both optimal and 


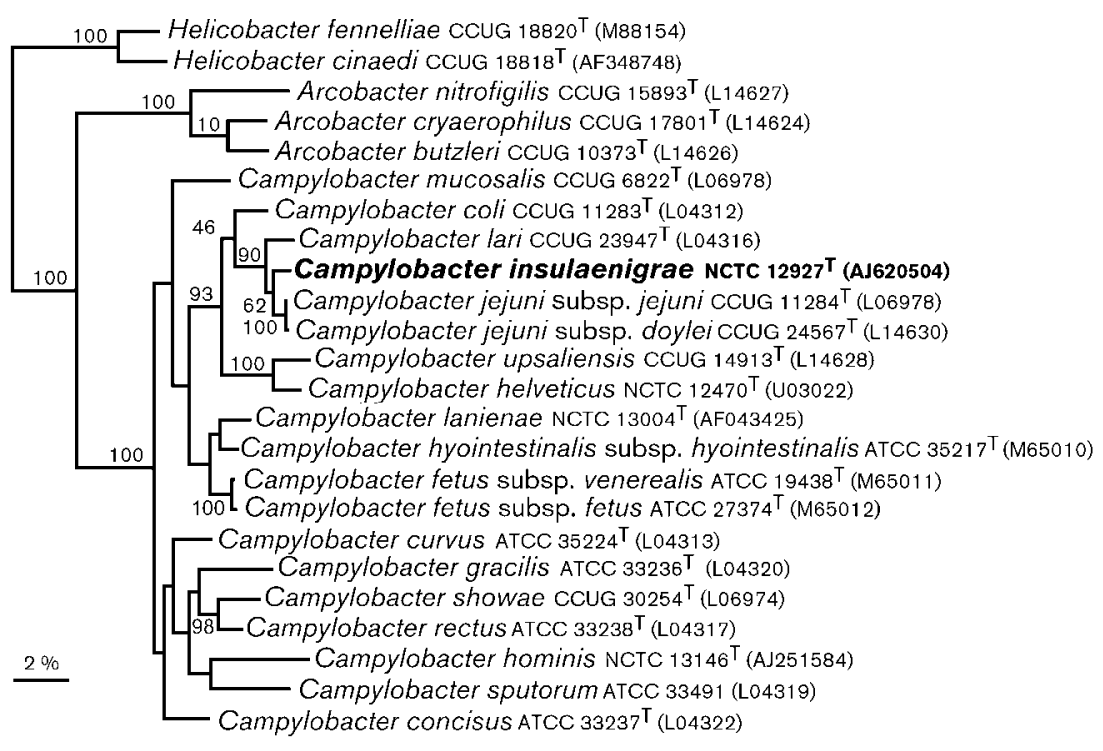

Fig. 1. Unrooted tree, based on $16 \mathrm{~S}$ rRNA gene sequences, showing the phylogenetic relationships of $C$. insulaenigrae $\mathrm{sp}$. nov. Bar, $2 \%$ sequence divergence. stringent hybridization conditions, thereby demonstrating that they are members of a single genomic species. This was consistent with very low divergence $(\% \mathrm{D})$ values. By contrast, $C$. lari displayed a relative binding ratio of $61 \%$ under optimum conditions and $33 \%$ under stringent conditions, with a $\mathrm{D}$ value of $11.7 \%$ with respect to the reference organism (strain NCTC $12927^{\mathrm{T}}$ ). Significantly lower relative binding ratios and higher $\% \mathrm{D}$ values were shown between the unknown bacterium and C. jejuni and C. coli (Table 1).

In the present study, we have comprehensively characterized four strains of a hitherto unknown bacterium recovered from three common seals and a porpoise in Scotland. It is evident from the results of the polyphasic taxonomic study that the unidentified Campylobacter-like isolates represent a novel Campylobacter species. Phylogenetically, the unknown bacterium shows close affinity with C. jejuni, C. lari and C. coli, displaying high $16 \mathrm{~S}$ rRNA

Table 1. Relative binding ratio and divergence of DNA from C. insulaenigrae sp. nov. NCTC $12927^{\top}$

$\mathrm{RBR}$, Relative binding ratio; \%D, percentage divergence.

\begin{tabular}{|c|c|c|c|}
\hline \multirow[t]{2}{*}{$\begin{array}{l}\text { Source of } \\
\text { unlabelled DNA }\end{array}$} & \multicolumn{3}{|c|}{$\begin{array}{l}\text { Results with labelled DNA } \\
\text { from NCTC } 12927^{\mathrm{T}}\end{array}$} \\
\hline & $\begin{array}{c}\mathrm{RBR} \text { at } \\
50^{\circ} \mathrm{C}\end{array}$ & $\% \mathrm{D}$ & $\begin{array}{c}\mathrm{RBR} \text { at } \\
65^{\circ} \mathrm{C}\end{array}$ \\
\hline \multicolumn{4}{|l|}{ C. insulaenigrae sp. nov. } \\
\hline NCTC $12927^{\mathrm{T}}$ & 100 & $0 \cdot 0$ & 100 \\
\hline NCTC 12928 & 86 & $0 \cdot 5$ & 88 \\
\hline NCTC 12929 & 91 & 0.6 & 89 \\
\hline NCTC 12930 & 90 & $0 \cdot 7$ & 86 \\
\hline C. lari NCTC $11352^{\mathrm{T}}$ & 61 & $11 \cdot 7$ & 33 \\
\hline C. jejuni NCTC $11351^{\mathrm{T}}$ & 31 & $15 \cdot 1$ & 8 \\
\hline C. coli NCTC $11366^{\mathrm{T}}$ & 33 & $16 \cdot 0$ & 7 \\
\hline
\end{tabular}

sequence similarity (approx. $1 \cdot 2-2 \cdot 4 \%$ divergence). Despite the relatively high sequence similarities between the unidentified isolates and these species, DNA-DNA pairing studies show that the strains from sea mammals form a genetically homogeneous group and represent a distinct genomic species. The closest genetic relative to the unknown bacterium corresponds to $C$. lari, but the observed low relative binding ratio and high divergence (approx. $12 \%$ ) between strain NCTC $12927^{\mathrm{T}}$ and the type strain of C. lari demonstrated that the bacterium from sea mammals represents a distinct species. It is known that $C$. lari is a phenotypically and genomically heterogeneous species. In a recent study by Duim et al. (2004), several groups were discerned within this species. The isolates recovered from marine mammals also resemble $C$. lari phenotypically. However, the novel species can be differentiated from $C$. lari by its inability to grow at $42{ }^{\circ} \mathrm{C}$ or in the presence of $2 \%(\mathrm{w} / \mathrm{v}) \mathrm{NaCl}$. Therefore, on the basis of both phenotypic and molecular genetic evidence, we are of the opinion that the organisms from marine mammals merit classification as a novel species of the genus Campylobacter, for which the name Campylobacter insulaenigrae sp. nov. is proposed. Tests that serve to differentiate $C$. insulaenigrae from other members of the genus Campylobacter are shown in Table 2. It is pertinent to note that the four isolates of $C$. insulaenigrae were recovered from different animals and at different times. AFLP genetic profiling (Fig. 2) showed that the isolates were all genetically different from each other, thereby demonstrating that they represent different strains rather than a single clone.

\section{Description of Campylobacter insulaenigrae sp. nov.}

Campylobacter insulaenigrae (in.su.lae.ni'grae. L. fem. n. insula isle/island; L. adj. niger, -gra, -grum black; N.L. gen. fem. n. insulaenigrae of the Black Isle, a region of northern Scotland). 
Table 2. Differential characteristics of $C$. insulaenigrae sp. nov. and other members of the genus Campylobacter

Taxa: 1, C. insulaenigrae sp. nov.; 2, C. coli; 3, C. concisus; 4, C. curvus; 5, C. fetus subsp. fetus; 6, C. fetus subsp. venerealis; 7, C. gracilis; 8, C. helveticus; 9, C. hyointestinalis subsp. hyointestinalis; 10, C. hyointestinalis subsp. lawsonii; 11, C. jejuni subsp. doylei; 12, C. jejuni subsp. jejuni; 13, C. lanienae; 14, C. lari; 15, C. mucosalis; 16, C. rectus; 17, C. showae; 18, C. sputorum; 19, C. upsaliensis. Data are from this study, On et al. (1996) and Logan et al. (2000). Symbols: +, 90-100\% of strains positive; (+), 80-89\% of strains positive; d, 21-79\% of strains positive; $(-), 11-20 \%$ of strains positive;,$- 0-10 \%$ of strains positive; $\mathrm{w}$, weak.

\begin{tabular}{|c|c|c|c|c|c|c|c|c|c|c|c|c|c|c|c|c|c|c|c|}
\hline Characteristic & 1 & 2 & 3 & 4 & 5 & 6 & 7 & 8 & 9 & 10 & 11 & 12 & 13 & 14 & 15 & 16 & 17 & 18 & 19 \\
\hline Catalase & + & + & - & - & + & $(+)$ & d & - & + & + & $\mathrm{d}$ & + & + & + & - & $(-)$ & + & $\mathrm{d}$ & - \\
\hline \multicolumn{20}{|l|}{ Growth at/in: } \\
\hline $25^{\circ} \mathrm{C}$ & - & - & - & - & + & + & - & - & $(-)$ & - & - & - & - & - & - & - & - & - & - \\
\hline $42^{\circ} \mathrm{C}$ & - & + & d & $\mathrm{d}$ & $(+)$ & - & $\mathrm{d}$ & + & + & + & - & + & + & + & + & $(-)$ & $\mathrm{d}$ & + & $(+)$ \\
\hline $1 \%$ Glycine & + & + & d & + & + & - & + & d & + & $\mathrm{d}$ & $\mathrm{d}$ & + & - & + & $\mathrm{d}$ & + & $\mathrm{d}$ & + & + \\
\hline $2 \% \mathrm{NaCl}$ & - & - & $\mathrm{d}$ & $\mathrm{d}$ & - & - & $\mathrm{d}$ & $(-)$ & - & - & - & - & - & $(+)$ & + & $\mathrm{d}$ & + & + & - \\
\hline Oxidase & + & + & $\mathrm{d}$ & + & + & + & - & + & + & + & + & + & + & + & + & + & $\mathrm{d}$ & + & + \\
\hline Nitrate reduction & + & + & $(-)$ & + & + & + & $(+)$ & + & + & + & - & + & + & + & - & + & + & + & + \\
\hline $\mathrm{H}_{2} \mathrm{~S}$ in $\mathrm{TSI}$ & - & $\mathrm{d}$ & - & $(-)$ & - & - & - & - & + & + & - & - & - & - & + & - & $\mathrm{d}$ & + & - \\
\hline Indoxyl acetate hydrolysis & - & + & - & $\mathrm{d}$ & - & - & $\mathrm{d}$ & + & - & - & + & + & - & - & - & + & $\mathrm{d}$ & - & + \\
\hline Hippurate hydrolysis & - & - & - & $(-)$ & - & - & - & - & - & - & + & + & - & - & - & - & - & - & - \\
\hline Microaerobic growth & + & + & + & $\mathrm{d}$ & + & + & - & + & + & + & + & + & + & + & + & - & $\mathrm{d}$ & + & + \\
\hline Anaerobic growth & - & - & + & + & $\mathrm{d}$ & d & + & - & - & + & - & - & $\mathrm{W}$ & - & + & + & + & + & - \\
\hline
\end{tabular}

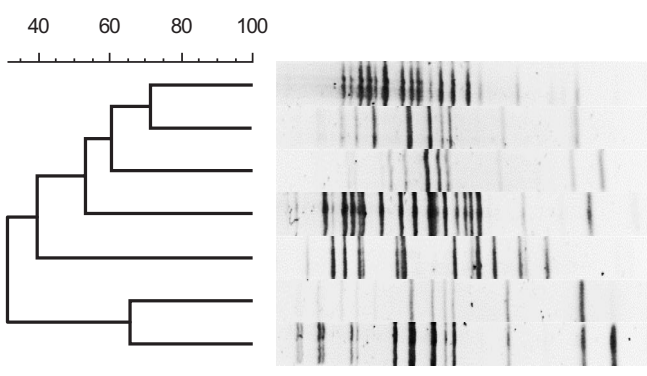

\author{
NCTC $11351^{\top} \quad$ C. jejuni \\ NCTC 12929 C. insulaenigrae \\ NCTC 12930 C. insulaenigrae \\ NCTC $11366^{\top}$ C. coli \\ NCTC $11352^{\top}$ C. lari \\ NCTC 12928 C. insulaenigrae \\ NCTC $12927^{\top}$ C. insulaenigrae
}

Fig. 2. Dendrogram of SAFLP profiles digested with Hindlll. Cluster analysis was performed with BIONUMERICS (Applied Maths), using the Dice correlation coefficient and the UPGMA clustering algorithm.
The following description of morphological and physiological characteristics is based on the results of studies of four strains. Gram-negative, motile, non-encapsulated, nonspore-forming, comma-shaped rods. Colonies on CSBA incubated in a microaerobic atmosphere at $37^{\circ} \mathrm{C}$ for $48 \mathrm{~h}$ are $0.75-1.0 \mathrm{~mm}$ in diameter, circular, entire, low-convex, smooth, shiny, grey, translucent, butyrous and easily emulsified. Growth does not occur at 25 or $42{ }^{\circ} \mathrm{C}$, or in aerobic or anaerobic atmospheres. Growth occurs in the presence of $1 \%(\mathrm{w} / \mathrm{v})$ glycine but not in the presence of 2 or $3.5 \%(\mathrm{w} / \mathrm{v}) \mathrm{NaCl}$. Oxidase- and catalase-positive, but urease-negative. Nitrates are reduced, but nitrites are not reduced. $\mathrm{H}_{2} \mathrm{~S}$ is produced in TSI agar, but hippurate and indoxyl acetate are not hydrolysed. Resistant to $30 \mu \mathrm{g}$ cephalothin and $30 \mu \mathrm{g}$ nalidixic acid $\mathrm{ml}^{-1}$.

The type strain is NCTC $12927^{\mathrm{T}}$ (=CCUG $48653^{\mathrm{T}}$ ). Isolated from marine mammals.

\section{Acknowledgements}

The Scottish Strandings Scheme is operated under contract with the UK Department of Environment, Food and Rural Affairs as a contribution to its coordinated programme of research on the North Sea. We acknowledge the contributions of Bob Reid and Bob Owen.

\section{References}

Brenner, D. J., McWhorter, A. C., Knutson, J. K. \& Steigerwalt, A. G. (1982). Escherichia vulneris: a new species of Enterobacteriacae associated with human wounds. J Clin Microbiol 15, 1133-1140.

Champion, O. L., Best, E. L. \& Frost, J. A. (2002). Comparison of pulsed-field gel electrophoresis and amplified fragment length polymorphism techniques for investigating outbreaks of enteritis due to campylobacters. J Clin Microbiol 40, 2263-2265.

Cooper, I. A. \& Slee, K. J. (1971). Human infection by Vibrio fetus. Med J Aust 1, 1263-1267.

Dekeyser, P., Gossuin-Detrain, M., Butzler, J. P. \& Sternon, J. (1972). Acute enteritis due to related vibrios: first positive stool cultures. J Infect Dis 125, 390-392.

Duim, B., Wagenaar, J. A., Dijkstra, J. R., Goris, J., Endtz, H. P. \& Vandamme, P. A. R. (2004). Identification of distinct Campylobacter lari genogroups by amplified fragment length polymorphism and protein electrophoretic profiles. Appl Environ Microbiol 70, 18-24.

Felsenstein, J. (1989). PHYLIP - phylogeny inference package (version 3.2). Cladistics 5, 164-166.

Gibson, J. R., Slater, E., Xerry, J., Tompkins, D. S. \& Owen, R. J. (1998). Use of an amplified-fragment length polymorphism technique to fingerprint and differentiate isolates of Helicobacter pylori. J Clin Microbiol 36, 2580-2585. 
Griffiths, P. L. \& Park, R. W. A. (1990). Campylobacters associated with human diarrhoeal disease. J Appl Bacteriol 69, 281-301.

Lipman, D. J. \& Pearson, W. R. (1985). Rapid and sensitive protein similarity searches. Science 227, 1435-1441.

Logan, J. M. J., Burnens, A., Linton, D., Lawson, A. J. \& Stanley, J. (2000). Campylobacter lanienae sp. nov., a new species isolated from workers in an abattoir. Int J Syst Evol Microbiol 50, 865-872.

McFadyean, J. \& Stockman, S. (1913). Report of the Departmental Committee appointed by the Board of Agriculture and Fisheries to inquire into epizootic abortion. Part III. Abortion in sheep. London: HMSO.

On, S. L. W. (2001). Taxonomy of Campylobacter, Arcobacter, Helicobacter and related bacteria: current status, future prospects and immediate concerns. J Appl Microbiol 90, 1S-15S.

On, S. L. W. \& Holmes, B. (1991). Effect of inoculum size on the phenotypic characterization of Campylobacter species. J Clin Microbiol 29, 923-926.

On, S. L. W. \& Holmes, B. (1995). Classification and identification of campylobacters, helicobacters and allied taxa by numerical analysis of phenotypic characters. Syst Appl Microbiol 18, 374-390.

On, S. L. W., Holmes, B. \& Sackin, M. J. (1996). A probability matrix for the identification of campylobacters, helicobacters and allied taxa. J Appl Bacteriol 81, 425-432.

Penner, J. L. (1988). The genus Campylobacter: a decade of progress. Clin Microbiol Rev 1, 157-172.

Rasmussen, S. W. (1995). DNATools, a software package for DNA sequence analysis. Copenhagen: Carlsberg Laboratory.

Sebald, M. \& Véron, M. (1963). Base DNA content and classification of vibrios. Ann Inst Pasteur (Paris) 105, 897-910 (in French).

Thompson, P. M., Cornwell, H. J. C., Ross, H. M. \& Miller, D. (1992). Serologic study of phocine distemper in a population of harbor seals in Scotland. J Wildl Dis 28, 21-27.

Vandamme, P., Falsen, E., Rossau, R., Hoste, B., Segers, P., Tytgat, R. \& De Ley, J. (1991). Revision of Campylobacter, Helicobacter, and Wolinella taxonomy: emendation of generic descriptions and proposal of Arcobacter gen. nov. Int J Syst Bacteriol 41, 88-103. 